\title{
Ownership and Control in the Netherlands
}

Abe de Jong*, Rezaul Kabir*, Teye Marra* and Ailsa Röell ${ }^{\#}$

October 1998

* $\quad$ Tilburg University, The Netherlands

\# Tilburg University, The Netherlands and Princeton University, USA

Keywords: Ownership; Control; Corporate Governance

JEL classifications: G30; G32: G34 


\begin{abstract}
This paper analyses ownership and control structures of Dutch listed companies. Legislation effective since 1992 mandates all shareholders with holdings of 5 percent or more in Dutch companies to disclose their holdings. Our analysis shows that the average ownership stakes of the largest and the three largest shareholders are $27 \%$ and $41 \%$, respectively. The average ownership stakes of banks, insurance companies and other financial institutions are relatively low. We observe that voting rights are more concentrated than ownership rights; the use of a supervisory board representing interests of different stakeholders is ubiquitous; and listed companies use different forms of antitakeover defense measures.
\end{abstract}




\section{INTRODUCTION}

The main purpose of this paper is to exhibit some of the evidence available regarding the ownership and control of Dutch listed companies. The paper also describes the legal framework of firms in general and the disclosure of share ownership in particular, together with some of the specificities of the Dutch legal and institutional framework for corporate governance.

The paper is organised as follows. Section 2 of the paper presents important features of major forms of enterprises in the Netherlands. The purpose of this section is to place listed firms in context, and to give an idea of their relative importance. Section 3 describes the framework for reporting and publicising ownership stakes in the Netherlands. Section 4 presents our analysis on the ownership and control structure in Dutch listed companies. The summary and conclusions are presented in section 5.

\section{FORMS OF ENTERPRISES}

\subsection{Major legal entities ${ }^{1}$}

A firm is set up by a notary's deed that records the amount of capital and the number of shares issued, the identity of founding executives, the statutes including the name, the seat of business (which must be in the Netherlands), goals of business, the provisions for replacement of executives and any procedures for blocking the transfer of shares. A declaration of approval is needed from the Minister of Justice, who can deny it if shady people are involved or the proposed statutes do not conform to the law. All this information must be reported in the Company Register (handelsregister) maintained by the local Chamber of Commerce. The law specifies the information to be disclosed by individual firms on an ongoing basis (annual accounts, etc.). Such information is publicly available for viewing, while extracts and summaries are supplied on request at cost. 
The largest and most important firms that constitute legal entities in the Netherlands are public limited companies (Naamloze Vennootschap, $N V$ ) and private limited companies (Besloten Vennootschap, BV). Currently, there are about 2,000 NVs and more than $150,000 \mathrm{BV}$ s. The $N V \mathrm{~s}$ are quite small in number, although these are on average the largest firms. The $N V$ status is usually a prerequisite for listing on the Amsterdam Stock Exchange. Some less economically important legal forms include cooperatives, partnerships, associations, foundations and sole proprietorships. The entity of $B V$ was introduced only in 1971 when $N V$ s were first obliged by law to publish their annual accounts. Almost $90 \%$ of the 50,000 or so $N V$ s existing at that time subsequently converted to $B V$ status. BVs are generally smaller firms, and also sometimes used as a form of professional partnership.

Important differences between $N V \mathrm{~s}$ and $B V \mathrm{~s}$ concern transferability of shares and constraints on the issue and buyback of shares. An $N V$ can issue both bearer and registered shares while a $B V$ can only issue registered shares. Whereas the statutes of an $N V$ can limit the free transferability of shares, the statutes of a $B V$ must do so (except the possibly for transfers to other existing shareholders, close family and the $B V$ itself). Shares issue and buybacks are stricter for an $N V$ than for a $B V$. For example, a $B V$ can acquire up to $50 \%$ of its own issued capital while an $N V$ only $10 \%$ without ongoing shareholder approval. In a $B V$, the statutes can rule out pre-emptive rights for existing shareholders when new capital is issued. In an $N V$, a decision of the shareholder meeting is required.

All firms, which ordinarily employ at least 100 employees must set up a works council (ondernemingsraad). ${ }^{2}$ This is a body for representing and consulting the views of employees. It has a right to relevant information, a right to advise on major decisions (e.g. transfers of ownership, relocation and important investments); it can delay decisions it disagrees with for one month and appeal to the company chamber of the Amsterdam Court. Its permission is required for changes in social arrangements (pensions, working hours, wages, safety rules), and if it disagrees, the employer must obtain a local judge's decision to go ahead.

\footnotetext{
${ }^{1}$ Our description is primarily based on Slagter (1996) and Dorresteijn and Verhorst (1994).

${ }^{2}$ Firms with at least 35 employees for $1 / 3$ of normal working hours must also set up a works council, but with limited responsibilities.
} 
Firms with capital and reserves of at least $f 25 \mathrm{mln}$, a legal obligation to set up a works council, and at least 100 persons employed in the Netherlands fall under a special regulation widely known as the structural regime (structuurregeling). These frms are then obliged to set up a supervisory board (raad van commissarissen) which inherits many powers otherwise held by common shareholders. Such a board consists of at least three members; new members are appointed by cooptation by the board itself (unless the shareholders' meeting or the works council object), and the statutes can determine that one or more are to be government appointees. The supervisory board evaluates important managerial decisions, appoints and dismisses the management board (raad van bestuur) and draws up the yearly accounts (which are subjected to shareholder approval). In practice, the structural regime gives ordinary shareholders very little say in the appointment or removal of supervisory board members as well as the management.

The shareholders of a relatively smaller company (unless the company adopts the structural regime) appoint management (bestuur) and directors (commissarissen) and approve annual accounts. The management is held personally responsible for any misbehaviour prior to a bankruptcy, the presentation of misleading accounts, improper payment of taxes, taking on obligations to third parties that clearly cannot be met, and environmental damage. The shareholders' meeting has residual rights not allocated elsewhere, as well as the right to approve annual accounts, appoint accountants, increase and decrease the firm's capital, hire and fire management, appoint at least $2 / 3$ of directors and alter the statutes. By law, the statutes cannot require more than a 2/3 majority for most decisions.

\subsection{Listed companies}

Firms that want a listing on the stock exchange must sign a listing agreement (noteringsovereenkomst) which sets down trading rules and listing requirements such as the size and composition of the capital issued and the contents of the prospectus. The listing requirements of the Amsterdam Exchanges include the following: a history of at least five years, in at least three of which a profit must have been reported; at least $f 10 \mathrm{mln}$ of equity capital; and at least $10 \%$ of the equity capital must 
be available for trading with a market value of at least $f 10 \mathrm{mln}$. In addition, a listed firm must comply with additional requirements set down in the listing agreement, which include a code of behaviour regarding trading in its own shares by company insiders.

Since the abolition of the Official Parallel Market in October 1993 there has been only a one-tier market in Amsterdam. Recently, a second-tier market called the New Market Amsterdam has been established. Less stringent requirements are proposed for firms seeking a listing on this segment. This market is also linked to the German, French and Belgian second-tier markets under the 'Euro-NM' initiative: an attempt to develop a unified trading forum for small European companies.

As mentioned earlier, $N V_{\mathrm{s}}$ usually qualify for stock exchange listing. At the end of 1997, shares of 248 Dutch companies were listed on the Amsterdam Exchanges. These companies had a market capitalisation of 907 million guilders. Dutch stock market capitalisation represents more than 50\% of the GDP (see Moerland (1995) for an international comparison). A unique feature of the Dutch market is that a few large companies dominate the scene. Fifteen companies including Royal Dutch, Unilever, Philips, Elsevier, Ahold, Akzo Nobel, ING and ABN AMRO represent about $75 \%$ of total market capitalisation of Amsterdam Exchanges. Only Royal Dutch accounts for $21 \%$ of total market capitalisation.

\section{DISCLOSURE OF SHAREHOLDINGS}

\subsection{The legal framework}

To our knowledge there is no legal obligation to disclose ownership stakes in unlisted companies (except in the case of single-owner companies, where the identity of the owner must be recorded in a publicly accessible company register together with a written account of all transactions between the owner and the company). If the company has issued registered shares, as is the case for all $B V \mathrm{~s}$ and many $N V \mathrm{~s}$, its management obviously keeps a register of shareholdings, which must include the 
names and addresses of all shareholders. But, there is no legal obligation to make this information freely and conveniently accessible to the general public.

For listed companies, shareholders are subject to the disclosure requirements of the law that carries out the EU Transparency Directive 88/627, namely the Law on Disclosure of Shareholdings (Wet Melding Zeggenschapsrecht) which came into effect in February 1992. Shareholders in all listed companies must notify both the company and the Securities Board of the Netherlands (Stichting Toezicht Effectenverkeer) of any purchases or sales of share stakes. The Board was set up in 1988 to supervise stock exchange share trading on behalf of the Minister of Finance.

Under the Law, shareholders are obliged to notify any trade which leads their share stake to cross the notifiable boundaries of $5,10,25,50$ or $662 / 3 \%$. This obligation to notify applies to both voting rights and ownership (income) rights separately. At the same time, the investor must indicate whether the stake is indirect (middelijk), that is, held via a daughter company or a third party; and whether the stake represents a potential (potentieel) stake rather than a current one, for example in case of a convertible bond or a warrant.

The listed company concerned is obliged to transmit this information promptly to the Securities Board, which publishes the announcement in the financial press (in practice, Het Financieele Dagblad) in a standardised format, after verifying the information $^{3}$. Before the law was ammended in 1997, the company itself was responsible for making an announcement in a newspaper with nation-wide circulation. But, it was felt that direct publication of the information by the Board would be more transparent and less error-prone.

A major source of concern with the share stake database maintained by the Board is that over time, it has become increasingly contaminated. The main problem is that share stakes can and do cross the notifiable percentage boundaries whenever the total

\footnotetext{
${ }^{3}$ At the same time, the Amsterdam Exchanges' listing agreement requires the company to report all price-sensitive information promptly so that it can be made public by the exchange on its electronic information dissemination system. In practice, most mutations in large shareholdings would reasonably be considered price-sensitive, so that the information is likely to be made public on the exchange before the Securities Board publishes it.
} 
outstanding share capital of the company changes; for example as a result of employee option plans, stock dividends, or mergers paid for by issuing shares. A large shareholder, who takes no active part in this modification of the denominator, has no obligation to report the resulting change in his percentage stake even if his percentage stake crosses a notifiable boundary as a result of the dilution. Thus, over time the quality of the database, which is based on initial notifications of percentage stakes, has deteriorated. The Board has pleaded strenuously but unsuccessfully for a new law to institute a periodic (say annual) obligation for companies to report their total share capital and the holdings of their known large shareholders, so that the database would give a more accurate picture of current blockholdings. The government and a majority in the Parliament felt that periodic disclosure would impose an unnecessary burden on companies and large shareholders. The Board is so concerned by the contamination of its database that it has threatened to lock up its database and stop providing the data to third parties who request it (mostly multinationals, institutional investors, analysts and the press).

The disclosure law is viewed as a means of providing greater transparency regarding the ownership structure of listed companies. The Minister of Finance, however, indicated to the Parliament in 1996 that he felt its role was simply to make market movements visible. Opposition to the tightening of the law was not based on considerations of administrative cost alone: since 1995, a pressure group to protect the privacy of large individual shareholders has been working to limit information dissemination by the Securities Board.

In 1996, the Parliament passed a revised law on the disclosure of blockholdings which became effective in June 1997. The new law repairs several deficiencies of the old law.

- One important lacuna concerned pre-existing large shareholders of companies listed after the original law went into effect; such shareholders were not obliged to notify their stakes. From now on all initial shareholders in newly listed companies must disclose any large stakes ${ }^{4}$.

\footnotetext{
${ }^{4}$ Large shareholders in the 70 or so companies that were listed between February 1992 and June 1997 were given a July 11997 deadline to disclose their holdings. But, only 20 notifications had been
} 
- Professional intermediaries (banks, underwriters of new issues) who retain stakes of over 5\% 'on the shelf' three months after a new issue or placing, must disclose such stakes as these will be regarded as part of their investment rather than trading portfolio.

- Custodians of stocks are now exempt from the obligation to disclose provided that they have no control rights.

- There is now a standard form on which information must be disclosed. The information must include the exact date on which the notification obligation arose and the details of how the stake is held (e.g. via a daughter company).

- The law was rephrased in terms of six 'bands' $(0$ - 5, 5 - 10, 10 - 25, 25 - 50, 50 $662 / 3,662 / 3$ - above); shareholders must report any movement of their stake into a different band. In the past, people did not seem to realise that they also had to disclose whenever their stake crossed a boundary downwards (a significant source of inaccuracy in the data).

- Both open-end and closed-end funds now have a weaker disclosure obligation, with $0-25 \%$ treated as one band.

- If a natural person discloses a stake, his/her 'daughter' company does not need to do so as well (this was already the case for group companies under the old law). Thus, double notifications are reduced.

- The Securities Board is empowered to correct inaccurate data.

Until May 1997, there were a total of 3300 disclosures. The notifying listed company pays the processing cost to the Board, which is currently running at about $f 2300$ excluding the cost of newspaper publication.

\subsection{Public availability of data}

The Securities Board itself does not provide a record of disclosures in electronic form; indeed, in May 1997 it announced that it would no longer provide data to third parties at all because of its concerns about the inaccuracy of its database. Starting in 1992, when the disclosure law first went into effect, the main Dutch financial newspaper Het Financieele Dagblad has periodically published a supplement with a complete 
overview of all disclosed blockholdings, based on the original situation in 1992 adjusted by intervening announcements of changes.

The database has over time become increasingly inaccurate for a number of reasons. First of all, when shareholders' proportional stakes are changed, not by any trading of their own but by changes in the total amount of issued capital of the company, they do not need to report such changes. In addition, shareholders tend to be forgetful about notifying decreases in their stakes. There have also been cases of large shareholders attempting to avoid or delay disclosure in order to hide their controlling interest from the public eye $e^{5}$. Lastly, pre-existing large shareholders in the 70 or so companies newly listed between February 1992 and June 1997 have not until July 1997 been obliged to disclose their stakes.

The newspaper Het Financieele Dagblad has taken some measures to improve the accuracy of the data. Whenever there is a series of filings by the same shareholder in the same company, only the most recent one has been kept. Any disclosures of stakes strictly below $5 \%$ have been eliminated. Remnants of overlapping stakes (direct and indirect), arising after reporting only one sale, have been removed. Some disclosures that have been published in the press but apparently not sent to the Securities Board are included.

The data is reported in the newspaper as follows. For each blockholding six categories are distinguished:

a. Total ownership (capital, dividend) rights (includes b and c).

b. Indirect ownership (held by a subsidiary or a firm with which the filing firm has a long term agreement on joint policies in exercising the voting rights).

c. Potential ownership, for example from warrants, convertibles, or call options.

d. Voting rights (includes e and $\mathrm{f}$ ).

e. Indirect voting rights.

f. Potential voting rights

roughly four notifications per company involved.

${ }^{5}$ Het Financieele Dagblad, May 7, 1993. Possible sanctions range from polite reminders to fines and imprisonment. 
Clearly, these data are imperfect and further cleaning up work is needed before they can be used in empirical research. For example, indirect holdings need to be clarified. Sometimes in-depth perusal of the original notifications may be enough; but sometimes it may be necessary to contact the persons and/or companies involved, in hopes that they will be forthcoming with the information. The earlier mentioned change in the data over time due to changes in the denominator is hard to deal with unless the relevant law is tightened. Information on share stakes of directors and company insiders is only available when they are reported under the disclosure law. This means, insiders can hide the trade as long as their stakes are less than 5\%. There exists no other requirement for insiders to make their transactions public.

For all its deficiencies, the data reported in the financial daily is the only one currently available, and in the next section, we will base our quantitative analysis on it.

\section{OWNERSHIP STRUCTURE AND VOTING RIGHTS}

\subsection{The sample}

As mentioned before, the Dutch disclosure requirements concern only the listed firms and shareholdings of at least 5\%. The ownership data are taken from the annual overview published in Het Financieele Dagblad on May 28, 1996. The data describe the situation on May 8, 1996. The sample consists of 137 Dutch industrial companies listed on the Amsterdam stock exchange.

As in the Netherlands no groups of listed companies are found, we do not analyse groups separately. In addition, we focus on direct holdings only. Regarding indirect holdings, we can only obtain information on stakes of listed firms in other listed firms. Thus, the data for indirect holdings would still be incomplete. In any case, the data for the listed firms only reveal few and minor stakes, and no controlling stakes.

We make three adjustments to the data reported in the newspaper. First, many Dutch firms issue a large proportion of their common shares to an administrative office, which in turn issue depository certificates to other investors after detaching voting 
rights. Ownership stakes reported by these administrative offices are excluded to avoid double counting. Because of the voting eligibility of administrative offices, their ownership stakes are included in the analysis of voting rights. Second, reported potential ownership stakes are not taken into account. In general, these potential rights are non-paid up preferred stock placed in a friendly foundation (generally called stichting preferente aandelen or stichting continuiteit). Third, the reported indirect ownership stakes may lead to double counting, as both the subsidiary and the parent may have filed information on the same stake. Indeed, if the parent is a person and not a company, that was obligatory under the pre-June 1997 law. We try to correct for this by eliminating the stake of the subsidiary. The following example using data of a company (Wegener) illustrates our procedure:

\section{Example: Disclosed shareholder stakes of WEGENER}

$\begin{array}{lllllll}\text { Shareholder } & \underline{\mathrm{a}} & \underline{\mathrm{b}} & \underline{\mathrm{c}} & \underline{\mathrm{d}} & \underline{\mathrm{e}} & \underline{\mathrm{f}} \\ \text { Amev/VSB NV } & 5.15 & 5.15 & 0 & - & - & - \\ \text { Britt Holding BV } & 5 & 0 & 0 & - & - & - \\ \text { Heinsbroek, H.Ph.J.E. } & 5.837 & 0 & 0 & - & - & - \\ \text { Houwert, C.J. } & 21.27 & 21.27 & 0 & - & - & - \\ \text { Loeff Beheer, BV van der } & 21.27 & 0 & 0 & - & - & - \\ \text { Scottish Widows Invt. } & 5.38 & 0 & 0 & - & - & - \\ \text { Telegraaf, Holdingsmij NV } 15.93 & 15.93 & 0 & - & - & - \\ \text { Wegener, St.Adm.Ktr } & 99.998 & 0 & 0 & 99.998 & 0 & 0 \\ \text { Wegener, St.Pref.Aand. } & 99.99 & 0 & 99.99 & 99.99 & 0 & - \\ \text { Wovang BV } & 5 & 0 & 0 & - & -\end{array}$

Note: The column headings are defined as follows: (a) total ownership rights (capital and dividend; it includes columns b and c); (b) indirect ownership (held by a subsidiary or a firm with which the filing firm has a long term agreement on joint policies in exercising the voting rights); (c) potential ownership (for example from warrants, convertibles, or call options); (d) voting rights (it includes columns e and f); (e) indirect voting rights; and (f) potential voting rights.

For Wegener we make the following adjustments. First, the reported single stake of 99.998\% by an administrative office ('Wegener, St. Adm. Ktr') is not taken into account in the analysis of ownership rights. Second, the potential stake of $99.99 \%$ of preferred stock reported by a foundation ('Wegener, St. Pref. Aand') is also deleted. Third, we investigate the indirect stakes as shown in columns b and e. Although in the row an indirect stake of Amev/VSB is reported, we can not find the direct shareholder 
because no stake of the same magnitude is reported. This entry is not deleted. An individual called C. J Houwert reported an indirect stake of $21.27 \%$. A private company named Van der Loeff Beheer has reported a stake of exactly the same percentage. It is very likely that C.J. Houwert controls Van der Loeff Beheer. For this reason this latter entry is deleted. As with the stake of Amev/VSB, the stake of Telegraaf shows no clear resemblance with the other stakes. We choose to remove double entries as much as possible by eliminating the subsidiaries.

\subsection{Ownership}

Table 1 presents summary information on the ownership (of income rights) structure of Dutch listed companies. We find that the mean (median) size of the largest blockholder is $26.94 \%$ (18.22\%), that of the three largest blockholders is $40.64 \%$ (34.05\%), and that of all blockholders together is $47.74 \%$ (48.4\%). Considerable variation exists among the ownership stakes. The standard deviation of the largest ownership stakes is $22 \%$ and that of the three largest blockholders is $28 \%$. The frequency distribution of share ownership is presented in table 2 . We see that relatively large number of firms have ownership stakes within the ranges of $25-50 \%$ and $50-75 \%$. Figures 1 and 2 provide graphical representations of the largest stake.

The results analysing ownership based on a broad categorisation of different types of investors are reported in Table 3. The average ownership stakes of banks, insurance companies and other financial institutions are $7.44 \%, 10.44 \%$ and $14.66 \%$, respectively. There are 78 firms with banks as a blockholder and 44 firms with insurance companies as another blockholder. Individuals and corporations have average stakes of $10.80 \%$ and $2.41 \%$ respectively.

\subsection{Voting rights}

Tables 4, 5 and 6 repeat the analysis for voting rights. The average size of the largest voting stake is $42.78 \%$. We observe that voting rights in Dutch companies are more concentrated than ownership rights. This is mainly due to the presence of blocks controlled by administrative offices which can be seen from Table 6 . We find that other categories of owners like banks, insurance companies, pension funds have, on 
average, very low voting rights.

\section{$4.3 \quad$ Takeover defenses}

Most Dutch listed companies have adopted several antitakeover measures. One commonly used device for denying voting rights to common shareholders is to set up an administration office (administratiekantoor) that holds original shares and issues depository certificates instead. Certificate holders retain the right to attend and speak at shareholders' meetings, to challenge the legitimacy of company decisions, and to call for extra meetings just like any shareholder. They also receive dividends. But, they have no voting rights. Votes can only be exercised by the administrative office.

Another very common method of defence against hostile takeovers is to issue preferred shares to friendly hands. The objective is not to raise capital but to change the balance of power in the shareholders' meeting. Priority shares with specific control rights are issued to friendly parties. For example, these shareholders may have the right to make a binding nomination for the appointment of management. A detailed analysis of these and other defense measures in the Netherlands is provided by Kabir, Cantrijn and Jeunink (1997).

Table 7 describes the use of administrative offices which issue share certificates. We select all shareholdings labelled under administrative offices and continuity foundation, excluding any stakes that represent a potential rather than a current interest. We find that 54 (39\%) of the 137 firms in the sample used this device of antitakeover defense. In the majority of these cases, more than two-thirds of the firm's share capital was certificated.

Table 8 describes another common device for countering the threat of takeovers: the use of potential capital which is only issued under specified circumstances, such as when the continuity of the firm is under threat (in other words, in case of takeover threats). These potential claims are typically held by a friendly foundation. We limit our table to those firms where potential capital is at least $25 \%$ of the currently outstanding capital (thus excluding various individuals and employee share option schemes which typically hold no more than about a $10 \%$ stake). Note that potential stakes can and do exceed $100 \%$ in some cases, as the denominator is currently 
outstanding capital. We find that 36 of the 137 sample firms have important amounts of potential capital. For 26 firms the amount of potential capital is even $98 \%$ or above, suggesting that the purpose of potential stakes is to achieve a voting majority of at least $50 \%$.

Different anitakeover devices may substitute or complement each other. Our results show that the use of nonvoting certificates and potential shareholdings do not seem to be substitute defence devices, as many firms use both. Eighteen firms use both an administrative office and have outstanding potential capital rights of over $25 \%$.

\subsection{Board supervision}

As mentioned earlier, most listed Dutch companies have a supervisory board the members of which are appointed by cooptation without direct shareholder input. A management board is in turn appointed by the supervisory board. There is much current debate on whether shareholders and employees of companies should have greater powers to appoint, re-appoint and depose supervisory board members.

As far as we know, there has not yet been any systematic quantitative information collected about Dutch supervisory boards. The only information available is the names of individuals acting as members of different Boards. According to the October 1996 report published by the Dutch Committee on Corporate Governance, 69 individuals are members of two Boards, 39 persons are members of three Boards, and 20 persons are members of at least four Boards. We collect information on board size of Dutch listed companies and report the results in Table 9. We find that median size of the management board is 2 while that of the supervisory board is 5 . The maximum number of members in the management board is 14 and that of the supervisory board is 11 .

Table 10 provides information on the percentage of shares owned by inside blockholders. The first column lists the 25 firms in which blockholders or members of their family are on the supervisory or the management board. The second and the third columns provide the percentage of shares owned by members of the management board and the supervisory board, respectively. In the fourth column the 
percentage of shares owned by people with the same family name as member of the management and the supervisory board is added. We can see that only in 19 firms, members of the management board have shareholdings greater than $5 \%$. For these firms, there is no change in insider blockownership when the su[ervisory board is added. There are 6 firms where members of the supervisory board hold stakes but those of the management board do not. The average ownership stakes of the management board members, the supervisory board members and family members (taken over our sample of 137 firms) are $4.86 \%, 1.82 \%$ and $0.49 \%$, respectively.

\section{CONCLUSIONS}

This paper studies ownership and control of Dutch industrial companies listed on the Amsterdam Exchanges. We find that the average share of the largest blockholder is 27 percent, and that of the three largest blockholders is 41 percent. We identify ownership by different groups and observe that banks, insurance companies and other financial instutions have, on average, low blockholdings. Analysing control aspects of Dutch companies, we find that adminstrative offices own major voting blocks. These and some other practices are used widely by Dutch listed companies as antitakeover measures which explain the absence of hostile takeovers in the Netherlands. 


\section{REFERENCES}

Commissie Corporate Governance, 1996, Corporate governance in Nederland, Amsterdam Exchanges.

Dorresteijn, A. and M. Verhorst, 1994, Inleiding bedrijfsrecht $\left(7^{\text {th }}\right.$ edition), Kluwer, Deventer.

Gelauff, G. and C. den Broeder, 1996, Governance of stakeholder relationships: the German and Dutch experience, Centraal Planbureau, Research Memorandum No. 127.

Het Financieele Dagblad, various issues.

Kabir, R., D. Cantrijn and A, Jeunink, 1997, Takeover defenses, ownership structure and stock returns in the Netherlands: an empirical analysis, Strategic Management Journal, vol. 18, pp. 97-109.

Moerland, P., 1995, Corporate ownership and control structures: an international comparison, Review of Industrial Organization, vol. 10, pp. 443-464.

Slagter, W., 1996, Compendium van het ondernemingsrecht ( $7^{\text {th }}$ edition), Kluwer, Deventer. 
Table 1. Ownership structure of Dutch companies.

\begin{tabular}{|c|l|l|l|l|l|l|c|}
\hline $\begin{array}{l}\text { Ownership } \\
\text { Concentration }\end{array}$ & Mean & Median & $\begin{array}{l}25^{\text {th }} \\
\text { percentile }\end{array}$ & $\begin{array}{l}75^{\text {th }} \\
\text { percentile }\end{array}$ & Minimum & Maximum & $\begin{array}{l}\text { Standard } \\
\text { deviation }\end{array}$ \\
\hline $\mathrm{C}_{1}$ & 26.94 & 18.22 & 9.42 & 44.65 & 0 & 97.05 & 21.60 \\
\hline $\mathrm{C}_{3}$ & 40.64 & 34.05 & 21.78 & 58.28 & 0 & 137.92 & 26.95 \\
\hline $\mathrm{C}_{5}$ & 45.29 & 44.59 & 26.96 & 65.22 & 0 & 144.36 & 27.57 \\
\hline $\mathrm{C}_{\mathrm{all}}$ & 47.74 & 48.40 & 27.70 & 69.69 & 0 & 144.36 & 28.92 \\
\hline
\end{tabular}

Note: The sample is 137 Dutch listed companies (investment funds excluded). Ownership data are analysed for 1996. Blockholders owning $5 \%$ or more are required to disclose ownership stakes. The concentration variables $\mathrm{C}_{1}, \mathrm{C}_{3}, \mathrm{C}_{5}$ and $\mathrm{C}_{\text {all }}$ represent the percentage of ordinary shares held by the largest blockholder, the three largest blockholders, the five largest blockholders, and all blockholders, respectively. Minimum concentration of 0 represents shareholdings of $5 \%$ or less. Maximum concentration of more than $100 \%$ is due to multiple disclosures of same shareholdings by different owners (ocurred in case of at least two firms). 
Table 2. Frequency distribution of ownership concentration.

\begin{tabular}{|c|c|c|c|c|c|c|c|c|c|c|c|c|}
\hline \multirow[t]{2}{*}{ Range } & \multicolumn{3}{|c|}{$\mathrm{C}_{1}$} & \multicolumn{3}{|c|}{$\mathrm{C}_{3}$} & \multicolumn{3}{|c|}{$\mathrm{C}_{5}$} & \multicolumn{3}{|c|}{$\mathrm{C}_{\text {all }}$} \\
\hline & Freq. & $\%$ & Cum. & Freq. & $\%$ & Cum. & Freq. & $\%$ & Cum. & Freq. & $\%$ & Cum. \\
\hline $0-5 \%$ & 3 & 2.19 & 2.19 & 3 & 2.19 & 2.19 & 3 & 2.19 & 2.19 & 3 & 2.19 & 2.19 \\
\hline $5-10 \%$ & 35 & 25.55 & 27.74 & 16 & 11.68 & 13.87 & 16 & 11.68 & 13.87 & 16 & 11.68 & 13.87 \\
\hline $10-25 \%$ & 40 & 29.20 & 56.93 & 25 & 18.25 & 32.12 & 12 & 8.76 & 22.63 & 12 & 8.76 & 22.63 \\
\hline $25-50 \%$ & 35 & 25.55 & 82.84 & 46 & 33.58 & 65.69 & 50 & 36.50 & 59.12 & 40 & 29.20 & 51.82 \\
\hline $50-75 \%$ & 21 & 15.33 & 97.81 & 31 & 22.63 & 88.32 & 34 & 24.82 & 83.94 & 39 & 28.47 & 80.29 \\
\hline $75-90 \%$ & 2 & 1.46 & 99.27 & 9 & 6.57 & 94.89 & 15 & 10.95 & 94.89 & 18 & 13.14 & 93.43 \\
\hline $90-95 \%$ & 0 & 0 & 99.27 & 3 & 2.19 & 97.08 & 3 & 2.19 & 97.08 & 5 & 3.65 & 97.08 \\
\hline $95-100 \%$ & 1 & 0.73 & 100 & 2 & 1.46 & 98.54 & 2 & 1.46 & 98.54 & 2 & 1.46 & 98.54 \\
\hline $100-$ & 0 & 0 & 100 & 2 & 1.46 & 100 & 2 & 1.46 & 100 & 2 & 1.46 & 100 \\
\hline
\end{tabular}

Note: The sample is 137 Dutch listed companies (investment funds excluded). Ownership data are analysed for 1996 . Blockholders owning 5\% or more are required to disclose ownership stakes. The concentration variables $\mathrm{C}_{1}, \mathrm{C}_{3}, \mathrm{C}_{5}$ and $\mathrm{C}_{\text {all }}$ represent the percentage of ordinary shares held by the largest blockholder, the three largest blockholders, the five largest blockholders, and all blockholders, respectively. In case of at least two companies, there were multiple disclosures of shareholdings the addition of which led to apparent ownership of more than $100 \%$. 
Figure 1. Cumulative distribution of the largest ownership block.

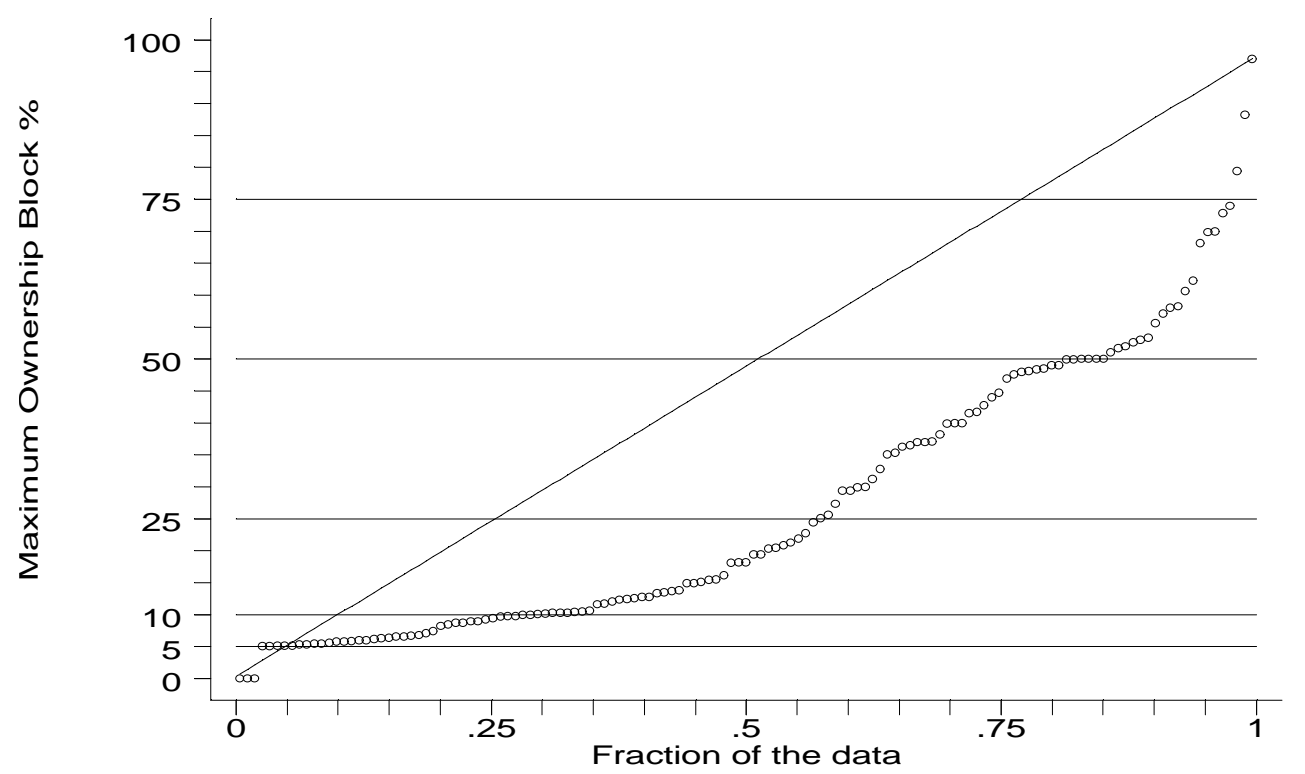

Figure 2. Histogram of the largest ownership block.

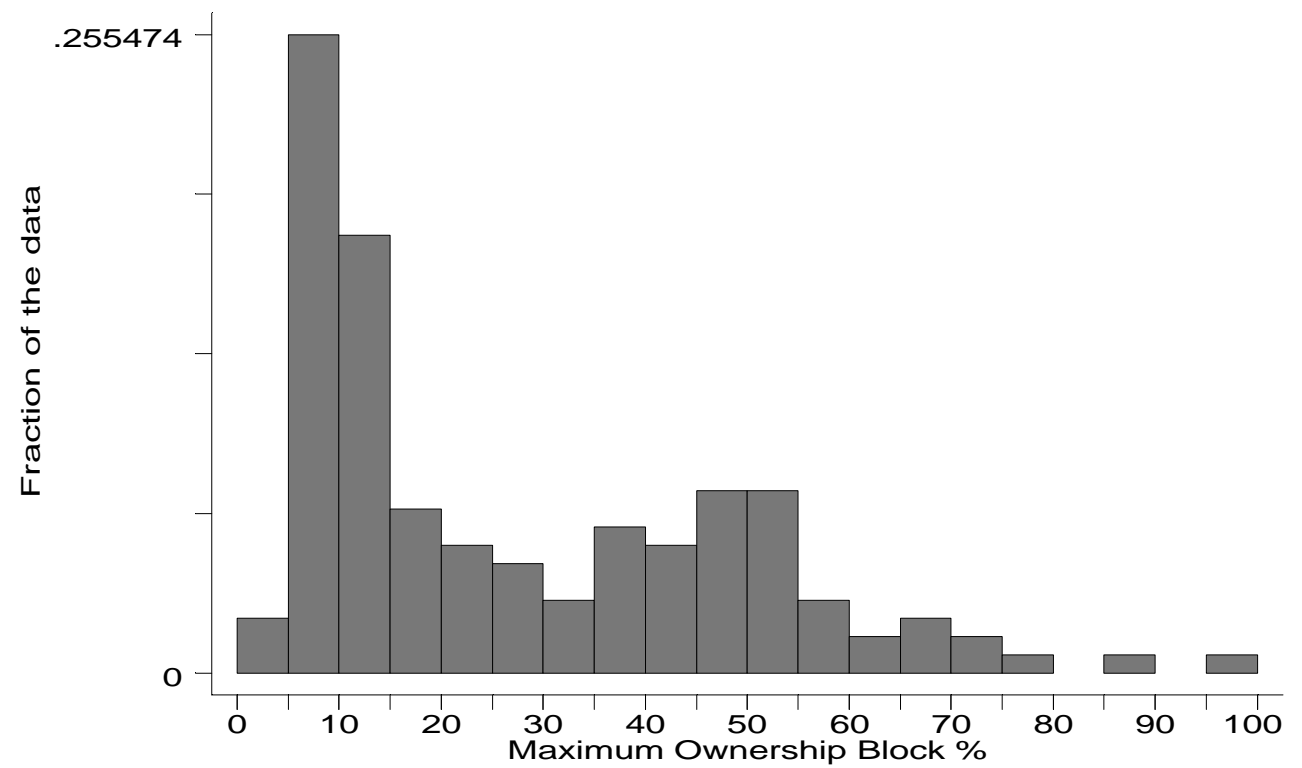



Table 3. Ownership structure by types of blockholders.

\begin{tabular}{|c|c|c|c|c|c|c|c|c|}
\hline & Banks & $\begin{array}{l}\text { Insurance } \\
\text { companies }\end{array}$ & $\begin{array}{l}\text { Other financial } \\
\text { institutions }\end{array}$ & $\begin{array}{l}\text { Pension } \\
\text { funds }\end{array}$ & $\begin{array}{l}\text { Venture } \\
\text { capitalists }\end{array}$ & Individuals & Industrial firms & State \\
\hline Mean & 7.44 & 10.44 & 14.66 & 0.60 & 0.30 & 10.80 & 2.41 & 1.08 \\
\hline Median & 5.14 & 0 & 8.52 & 0 & 0 & 0 & 0 & 0 \\
\hline Minimum & 0 & 0 & 0 & 0 & 0 & 0 & 0 & 0 \\
\hline Maximum & 58.28 & 93.17 & 85.61 & 19.06 & 18.09 & 97.05 & 27.01 & 50.00 \\
\hline Frequency & 78 & 44 & 87 & 10 & 3 & 48 & 38 & 4 \\
\hline
\end{tabular}

Note: The sample is 137 Dutch listed companies (investment funds excluded). Ownership data are analysed for 1996. Blockholders owning $5 \%$ or more are required to disclose ownership stakes. The concentration variables $\mathrm{C}_{1}, \mathrm{C}_{3}, \mathrm{C}_{5}$ and $\mathrm{C}_{\text {all }}$ represent the percentage of ordinary shares held by the largest blockholder, the three largest blockholders, the five largest blockholders, and all blockholders, respectively. The raw 'frequency' shows the number of firms where a particular type of blockholder is present 
Table 4. Concentration of voting rights in Dutch companies.

\begin{tabular}{|c|l|l|l|l|c|c|c|}
\hline $\begin{array}{l}\text { Voting } \\
\text { Concentration }\end{array}$ & Mean & Median & $\begin{array}{l}25^{\text {th }} \\
\text { percentile }\end{array}$ & $\begin{array}{l}75^{\text {th }} \\
\text { percentile }\end{array}$ & Minimum & Maximum & $\begin{array}{l}\text { Standard } \\
\text { deviation }\end{array}$ \\
\hline $\mathrm{C}_{1}$ & 42.78 & 43.46 & 11.21 & 60.79 & 0 & 99.99 & 32.10 \\
\hline $\mathrm{C}_{3}$ & 58.13 & 61.08 & 27.60 & 92.24 & 0 & 148.73 & 37.13 \\
\hline $\mathrm{C}_{5}$ & 61.05 & 67.51 & 34.90 & 92.59 & 0 & 148.73 & 36.73 \\
\hline $\mathrm{C}_{\text {all }}$ & 62.52 & 69.84 & 35.81 & 93.72 & 0 & 148.73 & 36.73 \\
\hline
\end{tabular}

Note: The sample is 137 Dutch listed companies (investment funds excluded). Voting rights data are analysed for 1996. Blockholders owning $5 \%$ or more are required to disclose ownership stakes. The concentration variables $C_{1}, C_{3}$, $\mathrm{C}_{5}$ and $\mathrm{C}_{\text {all }}$ represent the percentage of voting shares held by the largest blockholder, the three largest blockholders, the five largest blockholders, and all blockholders, respectively. Minimum concentration of 0 represents voting rights of $5 \%$ or less. Maximum concentration of more than $100 \%$ is due to multiple disclosures of same shareholdings by different owners (ocurred in case of at least eight firms). 
Table 5. Frequency distribution of voting rights concentration.

\begin{tabular}{|c|c|c|c|c|c|c|c|c|c|c|c|c|}
\hline \multirow{2}{*}{ Range } & \multicolumn{3}{|c|}{$\mathrm{C}_{1}$} & \multicolumn{3}{|c|}{$\mathrm{C}_{3}$} & \multicolumn{3}{|c|}{$\mathrm{C}_{5}$} & \multicolumn{3}{|c|}{$\mathrm{C}_{\text {all }}$} \\
\hline & Freq. & $\%$ & Cum. & Freq. & $\%$ & Cum. & Freq. & $\%$ & Cum. & Freq. & $\%$ & Cum. \\
\hline $0-5 \%$ & 14 & 10.22 & 10.22 & 14 & 10.22 & 10.22 & 14 & 10.22 & 10.22 & 14 & 10.22 & 10.22 \\
\hline $5-10 \%$ & 16 & 11.68 & 21.90 & 8 & 5.84 & 16.06 & 8 & 5.84 & 16.06 & 8 & 5.84 & 16.06 \\
\hline $10-25 \%$ & 19 & 13.87 & 35.77 & 12 & 8.76 & 24.82 & 5 & 3.65 & 19.71 & 5 & 3.65 & 19.71 \\
\hline $25-50 \%$ & 34 & 24.82 & 60.58 & 24 & 17.52 & 42.34 & 27 & 19.71 & 39.42 & 21 & 15.33 & 35.04 \\
\hline $50-75 \%$ & 27 & 19.71 & 80.29 & 26 & 18.98 & 61.31 & 23 & 16.79 & 56.20 & 25 & 18.25 & 53.28 \\
\hline $75-90 \%$ & 9 & 6.57 & 86.86 & 17 & 12.41 & 73.72 & 22 & 16.06 & 72.26 & 23 & 16.79 & 70.07 \\
\hline $90-95 \%$ & 7 & 5.11 & 91.97 & 8 & 5.84 & 79.56 & 9 & 6.57 & 78.83 & 11 & 8.03 & 78.10 \\
\hline $95-100 \%$ & 11 & 8.03 & 100 & 18 & 13.14 & 92.70 & 19 & 13.87 & 92.70 & 20 & 14.60 & 92.70 \\
\hline $100-$ & 0 & 0 & 100 & 10 & 7.30 & 100 & 10 & 7.30 & 100 & 10 & 7.30 & 100 \\
\hline
\end{tabular}

Note: The sample is 137 Dutch listed companies (investment funds excluded). Ownership data are analysed for 1996. Blockholders owning 5\% or more are required to disclose ownership stakes. The concentration variables $\mathrm{C}_{1}, \mathrm{C}_{3}, \mathrm{C}_{5}$ and $\mathrm{C}_{\text {all }}$ represent the percentage of voting shares held by the largest blockholder, the three largest blockholders, the five largest blockholders, and all blockholders, respectively. In case of at least eight companies, there were multiple disclosures of same shareholdings the addition of which led to apparent ownership of more than $100 \%$. The columns 'freq', '\%' and 'cum' show the number of firms, the percentage of firms and the cumulative percentage of firms, respectively. 

Figure 3. Cumulative distribution of the largest voting block.

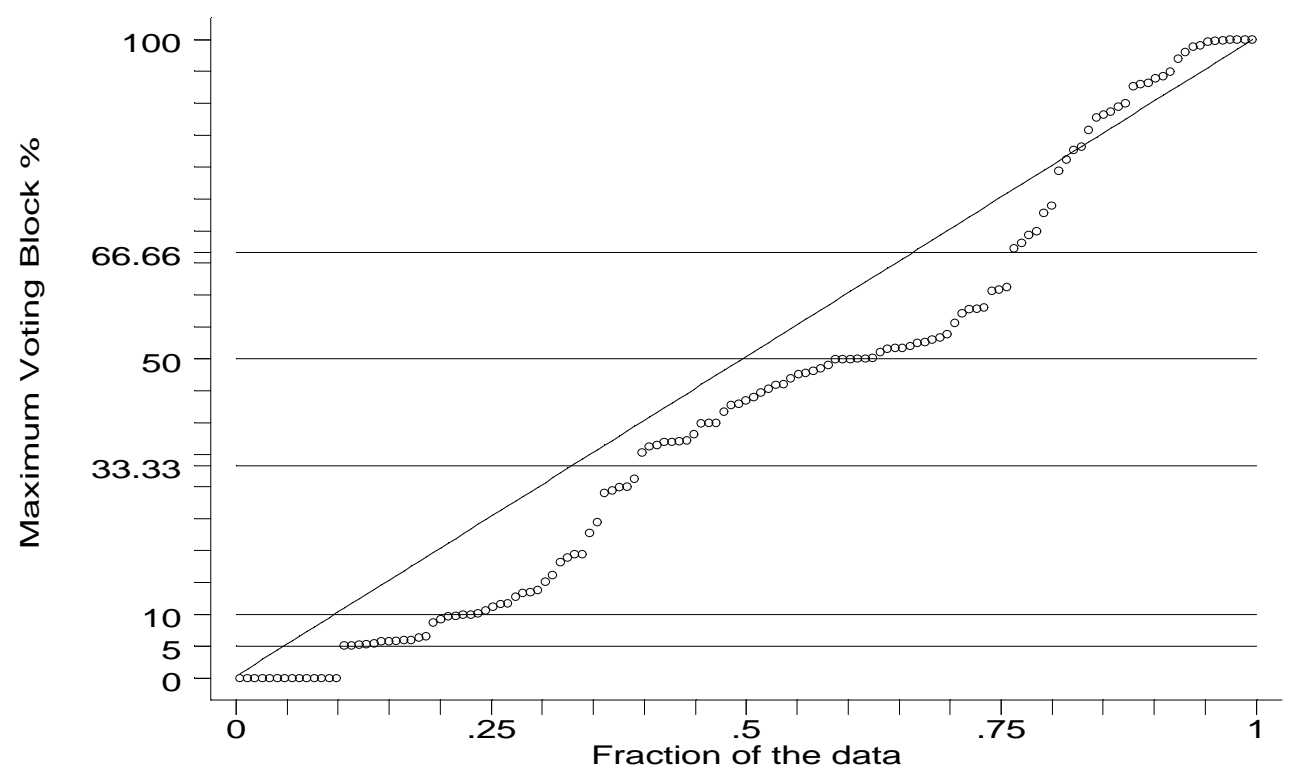

Figure 4. Histogram of the largest voting block.

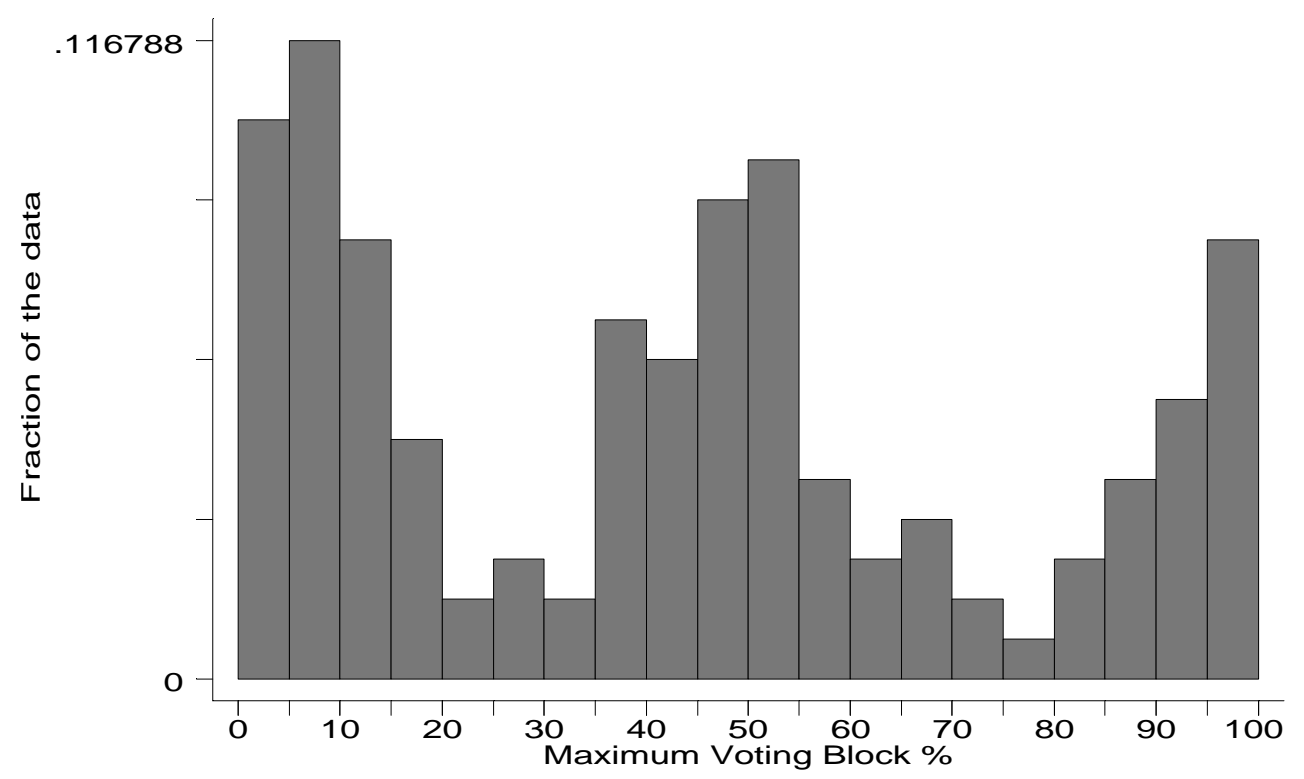



Table 6. Voting rights by types of blockholders.

\begin{tabular}{|c|c|c|l|c|l|c|c|c|c|}
\hline & Banks & $\begin{array}{l}\text { Insurance } \\
\text { companies }\end{array}$ & $\begin{array}{l}\text { Other financial } \\
\text { institutions }\end{array}$ & Pension funds & $\begin{array}{l}\text { Venture } \\
\text { capitalists }\end{array}$ & Individuals & $\begin{array}{l}\text { Industrial } \\
\text { firms }\end{array}$ & $\begin{array}{l}\text { State } \\
\text { tive Office }\end{array}$ \\
\hline Mean & 4.42 & 8.33 & 11.10 & 0.40 & 0.30 & 8.86 & 1.44 & 1.08 & 26.89 \\
\hline Median & 0 & 0 & 0 & 0 & 0 & 0 & 0 & 0 & 0 \\
\hline Minimum & 0 & 0 & 0 & 0 & 0 & 0 & 0 & 0 & 0 \\
\hline Maximum & 39.78 & 93.04 & 85.61 & 19.06 & 18.90 & 97.05 & 27.01 & 50.00 & 104.46 \\
\hline Frequency & 48 & 34 & 61 & 6 & 3 & 36 & 22 & 4 & 54 \\
\hline
\end{tabular}

Note: The sample is 137 Dutch listed companies (investment funds excluded). Ownership data are analysed for 1996. Blockholders owning $5 \%$ or more are required to disclose ownership stakes. The concentration variables $C_{1}, C_{3}, C_{5}$ and $C_{\text {all }}$ represent the percentage of voting shares held by the largest blockholder, the three largest blockholders, the five largest blockholders, and all blockholders, respectively. Maximum voting rights surpassed $100 \%$ because of multiple disclosures for the same shareholdings. The raw 'frequency' shows the number of firms with a particular type of blockholder. 
Table 7. Certification of common shares used by Dutch companies.

\begin{tabular}{|c|c|c|}
\hline & Number of firms & Percentage of firms \\
\hline Companies without share certificates & 83 & 61 \\
\hline $\begin{array}{l}\text { Companies with share certificates } \\
\text { These certificates are issued by at least } \\
\text { one administrative office with } \\
\text { shareholdings (x) of: }\end{array}$ & 54 & 39 \\
\hline$x \leq 25 \%$ & 5 & 3.6 \\
\hline $25 \%<x \leq 50 \%$ & 13 & 9.5 \\
\hline $50<x \leq 662 / 3 \%$ & 6 & 4.3 \\
\hline $662 / 3 \%<x \leq 90 \%$ & 11 & 8.0 \\
\hline $90<x \leq 99 \%$ & 9 & 6.6 \\
\hline $99 \%<x$ & 10 & 7.3 \\
\hline
\end{tabular}

Note: All shareholdings that are labelled under administrative office (administratiekantoor) or continuing foundation (stichting continuiteit) are included unless they represent potential rather than actual capital. In seven cases there were two (rather than one) administrative offices involved. 
Table 8. Companies with potential voting stakes over $25 \%$.

\begin{tabular}{|c|c|}
\hline & Number of firms \\
\hline No potential capital over 25\% reported & 101 \\
\hline $\begin{array}{l}\text { At least } 25 \% \text { potential capital } \\
\text { representing shareholdings (x) of: }\end{array}$ & 36 \\
\hline $25 \%<x \leq 50 \%$ & 8 \\
\hline $50 \%<x \leq 98 \%$ & 0 \\
\hline $98 \%<x \leq 100 \%$ & 26 \\
\hline $100 \%<x$ & 2 \\
\hline
\end{tabular}


Table 9. The size of the management board (MB) and the supervisory board (SB).

\begin{tabular}{|l|c|c|c|}
\hline \multirow{2}{*}{} & \multicolumn{3}{|c|}{ Board Size } \\
\cline { 2 - 4 } & Total & MB & SB \\
\hline Mean & 7.7 & 2.8 & 4.9 \\
\hline Median & 7 & 2 & 5 \\
\hline Minimum & 3 & 0 & 0 \\
\hline Maximum & 23 & 14 & 11 \\
\hline
\end{tabular}


Table 10. Ownership by inside blockholders in Dutch companies.

\begin{tabular}{|l|l|l|l|}
\hline & MB & SB & Family \\
\hline Free Record Shop Holding & 88,22 & 0,00 & 0,00 \\
Hollandia Kloos Holding & 77,10 & 0,00 & 0,00 \\
Automobiel Industrie Rotterdam & 55,63 & 0,00 & 0,00 \\
Randstad Holding & 53,06 & 0,00 & 0,00 \\
Content Beheer & 51,70 & 0,00 & 0,00 \\
Burgman Heybroek & 49,98 & 0,00 & 0,00 \\
Baan & 47,60 & 0,00 & 0,00 \\
Mulder Boskoop & 44,65 & 0,00 & 0,00 \\
Kondor Wessels groep & 35,35 & 0,00 & 5,50 \\
Drie Electronics Beheer & 24,40 & 0,00 & 24,40 \\
Aalberts Industries & 24,00 & 0,00 & 7,85 \\
Wegener & 21,27 & 0,00 & 0,00 \\
Delft Instruments & 20,41 & 0,00 & 0,00 \\
Rood Testhouse International & 19,40 & 0,00 & 0,00 \\
Tulip Computers & 17,53 & 0,00 & 0,00 \\
Dico International & 10,58 & 0,00 & 0,00 \\
Flexovit International & 8,78 & 0,00 & 0,00 \\
Nedcon Groep & 8,67 & 0,00 & 0,00 \\
Grolsch & 8,00 & 7,54 & 0,00 \\
Naeff & 0,00 & 97,05 & 0,00 \\
Cindu International & 0,00 & 46,93 & 0,00 \\
Neways Electronics International & 0,00 & 41,73 & 0,00 \\
Telegraaf & 0,00 & 29,41 & 0,00 \\
Gouda Vuurvast Holding & 0,00 & 13,60 & 18,20 \\
Sligro Beheer & 0,00 & 12,46 & 11,39 \\
\hline Average (over 137 firms) & & 1,82 & 0,49 \\
\hline
\end{tabular}

Note: The sample is 137 Dutch listed companies. The data on blocks of inside ownership are for 1996, and are expressed in percentages. MB stands for the management board; SB for the supervisory board; Family includes blockholders with the same surname as one or more members of one of the boards. 